\title{
Role of Unani Medicine in Prevention and Treatment of Waba (Epidemics) including COVID-19: A Review
}

\author{
Wasim Ahmad ${ }^{a *}$, Sayed Tauleha ${ }^{b}$, Mohammad Zulkifle $^{c}$, Ghulamuddin Sofi ${ }^{d}$ \\ ${ }^{a}$ Assistant Professor, Department of Kuliyate Tib, National Institute of Unani Medicine, Kottigepalya, Bengaluru, India- 560091. \\ ${ }^{b}$ P.G Scholar, Department of Kuliyate Tib, National Institute of Unani Medicine, Kottigepalya, Bengaluru, India- 560091. \\ Email: taulehabukhari20@gmail.com. \\ ${ }^{c}$ Head of the Department, Department of Kuliyate Tib, National Institute of Unani Medicine, Kottigepalya, Bengaluru, India- 560091. \\ Email: zulkiflenium@gmail.com. \\ ${ }^{d}$ Head of the Department, Department of IImulAdvia, National Institute of Unani Medicine, Kottigepalya, Bengaluru, India- 560091. \\ Email: sofi114@rediffmail.com.
}

Received: 22 May 2020 / Revised: 25 June 2020 / Accepted: 10 July 2020

\begin{abstract}
Mankind has faced many hardships like natural disaster, drought and epidemics. Study focuses on epidemics caused by microbes. Unani medicine has a long experience in treating epidemic diseases because its history is as old as the history of human being itself. More or less entire of the civilisations throughout the history became the basis for evolution of Unani medicine. Hippocrates (460- 380BC) regarded it asbothart and science, discussed the epidemics and wrote a book on Epidemics. Body is assumed healthy when the humours are balanced. So, Unani scholars have rightly said Fa'il (Active agent) is not able to produce any change (Actions \& Reactions) in the body without the prior presence of Munfa'il(Pertinent) having the capacity to accept it like in Waba(epidemic). The aim is to explore the fundamental concept of Waba from the Unani literature and understand COVID-19 in reference to existing literature of Unani medicine. The literature of Unani medicine was surveyed for concept of Waba(Epidemic) \& related concepts. Internet was used to access indexed papers using search engines like Medline, PubMed, Science Direct, etc. Logical preventive strategies like quarantine, and use of fumigants, prophylactic drugs are mentioned in Unani literature that have been used in epidemics with flue like symptoms. This knowledge and experience may be used for achieving methods for prophylaxis, cure or add on therapeutic measures for COVID-19 epidemic.
\end{abstract}

Keywords: Controlling measures, COVID-19, Philosophy, Waba.

(c) Euraass 2020. All rights reserved.

\section{Introduction}

The pathogenesis and symptoms of epidemics were first described by Hippocrates (460-380 BC) in his book Kitab ul Ahwiya, wal Miyah wal Buldan (The Book on Water, Air \& Places) wherein he used the term 'visiting 'translated by later physicians as
Amrazwafida. It means the disease affects a large group of a city at the same time. ${ }^{1,2}$ The disease is caused as a result of changes in air that is contrary to Tabiyat (Physis/Phusis) of human body. The changes of air either of Jauhar Hawa (Air substance) or transformation of the quality of air takes place. ${ }^{3}$ Hippocrates termed the constitution instead of season and these are four in numbers.

* Corresponding author. E-mail: drwasimkulliyat@gmail.com (Wasim Ahmed).

Available online: $15^{\text {th }}$ August 2020

DOI: https://doi.org/10.34154/2020-EJCS-0201-01-09/euraass

Cite this: Eur. J. Cell Sci. 2020, 2(1), $01-09$.

ISSN-E: 2679-3350.

(C) European Academy of Applied and Social Sciences. Euraass - 2020. All rights reserved. 
He ascribes their distinguished character by variable changes of each season. Also, he entitled the diseases that occur frequently in a particular constitution on the basis of their gross variability. In second constitution there is a continual fever of a serious character, which did not come to a crisis until after it had run a long course. $^{4}$ In fourth constitution the Galen and other authorities entitled it pestilential and has attracted great attention as being supposed to have derived its peculiar characters from the great plague which prevailed during the Peloponnesian war, and epidemical diseases, which are noticed by Hippocrates as having prevailed during this constitution. ${ }^{4}$ Moreover the description of various kind of fevers by Hippocrates in his 'Epidemics' are exactly the same as those which are now described as still prevailing in the land of Greece; that they correspond very well with those described by Cleghorn as occurring in Majorca. ${ }^{4}$

Among all kinds of existing fevers, the fever that belongs to buboes is bad with the exception of ephemerals; although the bubo is also the class of phlegmons as stated by Hippocrates. ${ }^{4}$ As per the 'Fragment'of Rufus' The buboes called pestilential are most fatal and acute, especially those which are seen about Libya, Egypt and Syria, and which are mentioned by Dionysius Curtis. ${ }^{4}$

The concept of changing merely in physical properties of air indicates deteriorated composition of air such condition of air called Waba. ${ }^{3,5}$ In other word Waba is a special type of infection that is caused through air in similar way as stagnant water becomes corrupted. ${ }^{3,5}$ In Unani literature the basic element, air is treated as Baseet(Simple) not Murakkab (Compound) then question arises as how it gets altered and becomes corrupted. ${ }^{3,5}$ The explanation provided by Unani physicians is that the surrounding air of the atmosphere is not Baseet but it is compound. It can be said that the air in atmosphere stands for that body which contains AjzaiMaiya (Droplets), AjzaiArziya (Dust), and AjzaiNariya (Fire part) along with the AjzaiHawaia (Air part) which is predominant. ${ }^{3,5}$ Here the changes are affected in the AjzaiHawaia and makes the environment susceptible to Waba. The Ufoonat (Putrefaction) occurs mostly in the end of season of summer and autumn.,

The changes in quality only mean unbearable of heat or cold thereby the crops and generations become destroyed and corrupted. ${ }^{3,5}$ It occurs in two ways IstihalaMujanisa (Likeness) and IstihalaMuzaddah (Antagonism/Contrast). ${ }^{3,5}$ In IstihalaMujanisa when the quality of season is too much hazardous i.e. the heat during the summer season is too much. Whereas, in IstihalaMuzaddah the quality of season becomes contrary to the quality it naturally has. It becomes much hazardous for instance; air becomes too cold in summer. When the air is about to alter then many complications are observed in inhabitants, because Akhlatof the body get corrupted. ${ }^{3,5}$

Earlier Ta'uoon was broadly intended to all kinds of epidemics, spread in very short period and killed up to large scale of populace, now it is exclusively proposed to a particular type of fever, caused by Yersinia Pestis, transmitted by fleas via rats. ${ }^{6}$ Ibn Sina says that it occurs by a toxic substance which produces fatal swelling in moist organs and glands of the body specially gland in the areas of armpit and groin. ${ }^{6}$

\section{Historical Background}

Justinian plague: One of the deadliest plagues, the outbreak initially started in Egypt in sixth century $A D$ and in very short span of time it extended to Constantinople, which was the capital of the Eastern Roman (Byzantine) Empire. It was named after the then"Byzantine Emperor Justinian". The outbreak was very severe and killed up to 25 to 100 million people. $^{7}$

Ta'uoon, in 18 Hijri, there was outbreak of epidemics in Syria, 55 thousand were killed even Governor of Syria was not spared. This outbreak started from then Amwas town (located in between Baitul Muqaddas and Ramla) and it extended across the Rome, Makkah, Hijaz, Baghdad and Khurasaan. Then the genius manAmar' bin Aas ordered the people to make distance among them and be dispersed across hills and towns and this way pandemic was controlled. ${ }^{8}$

Ta'unJarif, in 69 hijri, named due to excessive death in that epidemics persisted for three days. ${ }^{9}$

Ta'unFatayat, in 87 Hijri, it was spread in Iraq and Syria; initially it afflicts females and young girls before males hence, named as Fatayat. Some called it as Ta'unAshraaf because the death was observed mostly in lavish society. ${ }^{9}$

Ta'un Muslim b. Qutaiba, in 131 Hijri named because the first person killed by this disease. It happened in Basra and persisted for three months. It was so severe that in the month of Ramdhan thousands of deaths were recorded. ${ }^{9}$

In $422 \mathrm{Hijri}$, there was an outbreak of pandemic in most of the region of India, ghazna, Khurasaan, Ray, Asbahaan, surroundings of Moosal and Baghdad in the season of summer- autumn (JuneSeptember). In a few days forty thousand of peoples were killed. ${ }^{10}$

In $597 \mathrm{Hijri}$, there was outbreak of epidemics in Unza city (located between Hijaz and Yaman) there were 20 villages, 18 of them were plundered. ${ }^{10}$

In $656 \mathrm{Hijri} / 1258$ AD there was outbreak of pandemic persisted for 40 days in Baghdad, people of entire city were overthrown rarely anyone of them was spared. It extended up to Syria where a lot of deaths were registered due to presence of infection in atmospheric air. ${ }^{11}$

In 748 Hijri, Ta'un-al-Aazam named because of its pace of 
spread and high mortality rate. This Ta'uoon had killed the inhabitants of Halb, Dimashq, Quds and their coastal regions. Likewise, great disease "Al Fanaul Azeem" in 795 Hijri happened and 150 thousand were killed in Halab city alone. ${ }^{12}$

1798 AD Ta'uoon was spread in Europe through the travellers of Alexandria extended up to Tunis, Aljazair. ${ }^{13}$ Spanish Flue broke out during the last phase of First World War, was deadliest pandemic of the last century that killed up to 50 million people. ${ }^{7}$

\section{Causes}

The following are the identified causes of epidemic as stated in Unani medicine. Impure and wet nature air, excessive coitus, somebody retains Akhlatraddiya (Morbid matter), having widened pores, wet tempered body, having the history of excessive use of Hammam (bath), Bukharat (Putrefactive vapour) produced by refuge/litter of cities, slaughter house, industries, cremation ground, ditch/moth, improper biological waste management, global warming, deforestation, urbanisation, uncontrolled industrialisation and urbanisation etc. ${ }^{2,5,14}$

\section{Pathogenesis}

Once the man breathes in such form of air which is not in good state, then there is an admixture of this with the already corrupted Akhlat (Humour) present in the body. The consequence, of this admixture affects the Arwaah (Spirit) of the body as well and leads to development of AmrazRaddiya (Dreaded diseases). ${ }^{2}$ Jalinoos has mentioned/describes in his book Kitab alHummiyat (Book on Fever) that it is not possible for any agent to bring about any change in the body unless and until there is any proficiency of acceptance of that particular cause already. ${ }^{2,15}$ Similarly, Fa'il (active agent) is not able to produce any change (actions and reactions) in the body without the prior presence of Munfa'il (pertinent) having the capacity to accept the change like in Hummai Waba (Epidemic fever). ${ }^{5,14}$

Once the season changes from its natural state like the winter season will have changed to dry and hot and there will be either no rain or excessive raining. Similarly, in hot season or spring season there will be coldness and dryness. In case of autumn season, there will be hotness and wetness. So, there will be a change in each season from its natural form, especially the summer air will be replaced by winter air and there would be abundant raining and southern winds will blow leading to spread of epidemics like fatal kind of fevers, varieties of plagues and many other diseases. These epidemics would not spare even animals whether domestic or wild. The reason behind this being the corruption and vitiation of body fluids and Arwah. The plants, the trees, herbs and shrub would also get affected and there will be a deposition of a thick material like SheeraiAngoor (Grapes juice), on the trees. There will be dust on leaves, the fruits will be affected both in pulp and its covering. $^{2}$

When the air is much hot, it upsets the digestion by dissolution of HararatGhareeziyah (Innate heat), dissolving the AkhlatDamviyya (Sanguine) and changing the body colour to yellow by dominating KhiltSafra (Bilious) over other Akhlat. and there occurs changes in the Qalb(Heart) as the flowing Akhlat get corrupt and vitiation occur. Consequently, they are accumulated in spaces causing the weakness of organs. ${ }^{3}$

\section{Signs and Symptoms}

Dry cough, Tanaffusazeemwamutawatir (Difficulty in breathing) disorientation, feeling of various kinds of pain, sweating, cold extremities, burning in chest, dryness of tongue, fetid odour, thirsty, stretching and tensing in hypochondrium, nausea, bilious vomiting and diarrhoea, flatulence, stool is odorous and frothy, sometimes blackish. Urine is sometimes concentrated or diluted, and its colour is blackish, or yellowish, its Rusoob (Precipitate) has got Qashrwalakhte (Cast) in it, and odorous. ${ }^{2,14,16}$ Those patients are accustomed to fetid breath they are on high risk, and having poor prognosis. Even they don't realise that there is as much warmth in their body and or they have apparent manifestations because of Ufoonat. Pulse is Mutwatir (Continuous) and Sagheer (Small) often, splenomegaly, lethargy, and loss of appetite. ${ }^{2,5,14}$ Externally neither feeling cold nor hot so fever cannot be easily detected while person having bad prognosis for the disease. ${ }^{5,16}$ Running out of insects from their dwellings is the typical signs of epidemics. ${ }^{5}$

\section{Management of Epidemics}

\subsection{General anticipatory method}

The aim of general anticipatory method is to eliminate the morbid matter from the body and improve the immunity. ${ }^{5,14,15}$ Stay in well ventilated home thereby reduces the chances of contact amongst people and avoid cold air/ air-conditions. ${ }^{16}$ Ensure body dryness by practising Fasdwalshaal (Bloodletting and purgation), if there is predominance of blood Fasd is indicated, Istifragh(Elimination) of remaining Khilt may be practiced. ${ }^{5,14,15}$ No Hammam (Bath), no exercise. ${ }^{5,17}$ Taqlee/Ghiza (Less amount of food) since it has tendency of corruption..$^{5,14,16,18}$ Consumption of meat, alcohol, sweets, wet fruits, coitus during the period of Waba should be avoided. ${ }^{15,16,17,18}$

Use of fish is not indicated in times of outbreak. ${ }^{15,18}$ Ensure cleanliness of surroundings by proper disposal off waste/ refuges/litters in their appropriate places. ${ }^{14}$ Head cover or turban prevents air born infection or minimize air born epidemics as stated by Indian scholars. ${ }^{17}$

\subsection{Sanitization and decontamination of surroundings}

Sanitize and disinfect the surroundings by means of spray and 
fumigation. Hence it serves important medium for spreading and dissemination of virus. For this purpose, many drugs are mentioned as summarised in Table No. 1 as a mode of fumigants and spray. The curtains of the door, wearing cloths, and entire house will be sanitized and fumigated. Even branches of the trees; Bed Mushk (Salix caprea, Linn.), grape are placed in vicinity of house most of them are aromatic basis because the aromas/scents protect from

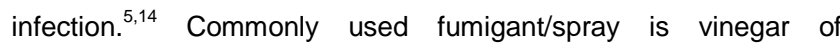
sugarcane or onion, garlic, and Sandal (Pterocarpus santalinus,Linn.), Kafoor (Cinnamomumcamphora), UoodKhaam (Aquilaria agallocha, Roxb.), Bed Mushk, Qustshirin (Saussurealappa), Zafraan (Crocus sativus), Chadela (Parmeliaperlata, Arch.), Ghaar (Laurus nobilis, Linn.), Nagar moth (Cyperusrotundus), Izkhar (Andropogonschoenanthus, Linn.), Ab'hal (Juniperuscommunis, Linn.), BadaamTalkh (Prunus amygdalus), Post Anaar (Punicagranatum, Linn.), Hilteet (Ferula asafoetida) is recommended. . $^{514,16,17}$

Peal of pomegranate, leaves or juice of lemon, leaves or orange juice, rose water, Sandal, Gul neelofar (Nymphea alba Linn.), Gul bed mushk etc. also recommended. ${ }^{14,16,17,18}$ A few last mentioned drugs has not only to produce exhilarant effects but also having antimicrobial effects. ${ }^{5,14,17}$ Lakhlakha (burning incense used for medicinal purposes); Kafoor and Arqgulab is practiced. ${ }^{14,17}$ BargJhau (Tamarix gallica), purify the wetness of air and hot and subtle nature's drug i.e. ginger cleanse the heaviness of air. ${ }^{17}$ Lobaan, (Styrax benzoin W.G.Craib), Me'asaila (Liquidamberoriantalis miller),Chandroos, Qaranfal (Eugenia caryophyllata, Thunb.), Kundur (Boswellia serrata), Murmaki (Commiphora myrrh), Sibr (Alovebarbadensis), Ratinajpurify the dry air. ${ }^{5,14,17}$

Even though Unani medicine has a lot of repository of drugs which act as antimicrobial, antiviral, anti-inflammatory and antipyretics but their clinical and pharmaceutical effects are not yet validated and reported in different journals.

\subsection{Recommendation for diets and drinks}

Cold extracts; Ma'urRaib (Curd water), chhaachh (Diluted curd), Arq Gulab (Rose water), Mis/Haamiz (Cheese water), drinking of Sirka (Vinegar) along with water, drinking of cold water in abundant quantity, Masoor (Lentil), onion, apple, Aas, Zafraan etc. 5,14,16,17 RoghanBadamshirin and RoghanGau eating and massaging to body parts daily, greased Haleela (Terminalia chebula), Tamar Hindi (Tamarindusindica, Linn.), Orange, Aabanar, Aab lemon, MaghzFloosKhayarShanmbar (Cassia fistula, Linn.), Sheer Khisht (Fraxinousornus, Linn.). ${ }^{18}$ In case of loss of appetite forced eating is advised because whoever has to be patient would survive otherwise disheartened ones will loss the battle of life. ${ }^{17}$ Consuming of TurshwaMujaffifaghziya (citrus and desiccant diet) in less quantity since diet gets corrupted easily. ${ }^{5,14,16,18}$ Meat should be cooked with citrus things, Hullam (Kind of animal jelly), Qarees (a variety of meat cooked with vinegar, vegetables and cumin), and that Masoos (a variety of meat dish) cooked with vinegar or prepared with other citruses i.e. Sumaq (Rhuscoriaria, Linn.), AabAngoorKhaam (Unripe grapes water), Aab Lemon (lemon water), or AabAnar (Pomegranate water), guava, apple, Behi (Cydonia vulgaris), Heeng, Kushkushshayeer (Dried barley) etc., cold and exhilarant based fruits, are indicated. ${ }^{14,16}$ Mukhallilat (Pickles) i.e. KibrMukhallal is very much useful that prevents Ufoonat. Jalinoos states that drinking of Gil Armani with vinegar and water is very much useful. ${ }^{19}$ Consumption of chicks, lamb meat, Teetar, calf meat is used with vinegar/AabHasram and Sumaq, and chews the meal or foodthoroughly. ${ }^{16,17}$

\subsection{Prophylactic drugs}

Unani scholars advocate about health protection by employing certain drugs during Waba. Both are single herbs/ shrubs and compound formulations are suggested in this respect. Imli (Tamarindusindica), Revandchini (Rheum emodi), Banafsha (Viola odorata, Linn.), HaleelaZard and Haleelasiyah (Terminalia chebula), Amaltas/ KhayarShanbar (Cassia fistula Linn), Turanjbeen (Hedy sarumAlhagi, Linn), Lablab/ Ishqpechan, Aabanar (water of pomegranate) these drugs have preventive effect on body as stated by Ibn Rushd. ${ }^{15}$

Elwa two parts, Zafran one part and Murmaki one part are pulverized and eaten a little amount daily along with SharabaRaihani (Ocimumpilosum,Wild.) $300 \mathrm{ml}$. Raufas says I didn't see anyone ever who expired. ${ }^{14,16,17,19}$

Sikanjabeen prepared from Arq Gulab, contains ingredients having the properties of diuretics, and cold nature are advised. ${ }^{15}$ Tiryaq Kabeer is indicated in a dose of $4 \mathrm{mg}$ to $4 \mathrm{gm}$, after taking it no food is taken up to 9 hours till it metabolised completely. ${ }^{15,17}$ Steam inhalation by following drugs; Kafoor, Qust, Kundur, Uood, Mushk, Murmakiare also recommended during epidemics. ${ }^{16}$

Administration of Gil Armani (Arminina bole) and Gil Makhtoom (Marl, Sealivg clay) along with vinegar is also useful. ${ }^{15}$ Jalinoos states that if in the season of epidemics Gil Armani, sirka and Namak used together are useful. ${ }^{16}$

If there is respiratory illness, then SharbatBanafsha $20 \mathrm{ml}$ and SharbatKhashkhash $20 \mathrm{ml}$ morning and evening are beneficial. If the patient has sore throat, then it could be replaced by Sharbat Toot siyah instead of Sharbat banafsha. ${ }^{20}$ 
Table 1: List of drugs used as fumigants during epidemics

\begin{tabular}{|c|c|c|c|c|}
\hline S.no. & Botanical name \& Family & Unani name & Part used & Mode of Action \\
\hline 1. & Viola odorata, Linn. (Violaceae) ${ }^{14,21,22,23,24}$ & Banafsha & Whole & $\begin{array}{l}\text { Antimicrobial, } \\
\text { Mosquito repellent }\end{array}$ \\
\hline 2. & $\begin{array}{l}\text { Nymphea alba, Linn. } \\
\text { (Nymphaeaceae) }^{5,14,16,17,25}\end{array}$ & Neelofar & Flower, Seed, Root & Antimicrobial \\
\hline 3. & Salix alba, Linn. (Salicaceae) $)^{5,14,16,11,26}$ & Bed sada & Flowers, Leaves & Antimicrobial \\
\hline 4. & $\begin{array}{l}\text { Rosa damascena, Mill. } \\
\text { (Rosaceae) })^{5,14,15,16,17,27,28}\end{array}$ & GuleSurkh & Distillate of petals & $\begin{array}{l}\text { Antiviral, } \\
\text { Antibacterial }\end{array}$ \\
\hline 5. & $\begin{array}{l}\text { Pterocarpus santalinus } \\
\mathrm{L}(\text { Santalaceae) })^{5,14,15,16,17,18,29}\end{array}$ & Sandal & Heartwood & Antimicrobial \\
\hline 6. & Styrax benzoin ${ }^{5,14,15,16,11,18,30}$ & Loban & Resin & Antimicrobial \\
\hline 7. & $\begin{array}{l}\text { Cinnamomumcamphora. } \\
\text { (Lauraceae) }^{5,14,15,16,17,18,31}\end{array}$ & Kafoor & Crystal, Oil & Antimicrobial \\
\hline 8. & Aquilaria agallocha, Roxb. $5,14,16,17,18$ & Ood & Wood & Antimicrobial \\
\hline 9. & Saussurealappa (Compositae) $)^{5,14,16,17,18,32,33}$ & Qust & Root & $\begin{array}{l}\text { Antimicrobial, } \\
\text { Pesticidal }\end{array}$ \\
\hline 10. & $\begin{array}{l}\text { Liquidamberoriantalis miller } \\
\text { (Altingiaceae) })^{14,16,17}\end{array}$ & Measaila & Resin & Antimicrobial \\
\hline 11. & $\begin{array}{l}\text { HymenaeaverrucosaGaertn } \\
\text { (Leguminosae) }\end{array}$ & Sandaroos & Resin & Antimicrobial \\
\hline 12. & Ferula asafoetida (Umbelliferae) $)^{5,14,16,17,34,35}$ & Hilteet & Gum, Resin & $\begin{array}{l}\text { Antiviral, } \\
\text { Antimicrobial, } \\
\text { Antiseptic }\end{array}$ \\
\hline 13. & $\begin{array}{l}\text { Eugenia caryophyllata, Thunb. } \\
\text { (Myrtaceae) }\end{array}$ & Qaranfal & Dry buds & $\begin{array}{l}\text { Antiviral, } \\
\text { Antimicrobial }\end{array}$ \\
\hline 14. & Crocus sativus (Iridaceae) ${ }^{5,14,16,11,18,38,39,40}$ & Zafran & Stamen & Antimicrobial \\
\hline 15. & Boswellia serrata (Burseraceae) ${ }^{41}$ & Kundur & Oleo gum resin & Antimicrobial \\
\hline 16. & Commiphoramyrrha (Burseraceae) ${ }^{42,43}$ & Murmaki & Oleo gum resin & Antiviral \\
\hline 17. & Cyperusrotundus (Cyperaceae) ${ }^{44,45,46,47}$ & $\begin{array}{l}\text { Nagarmotha/ Saad } \\
\text { Kofi }\end{array}$ & Root & $\begin{array}{l}\text { Insecticidal, } \\
\text { Antibacterial, } \\
\text { Repellent }\end{array}$ \\
\hline 18. & $\begin{array}{l}\text { Cymbopogon schoenanthus, } \\
\text { Linn.(Gramineae) } \\
48,49\end{array}$ & Izkhar & $\begin{array}{l}\text { Aerial parts of the } \\
\text { plant }\end{array}$ & $\begin{array}{l}\text { Insecticidal, } \\
\text { Antimicrobial }\end{array}$ \\
\hline 19. & Tamarix gallica ${ }^{50,51,52}$ & Jhau & Leaves \& Flower & Antimicrobial \\
\hline 20. & Punicagranatum(Lythraceae $)^{53}$ & Post Anar & Shell & Antimicrobial \\
\hline 21. & Zingiber officinalis (Zingiberaceae) ${ }^{54}$ & Zanjabeel & Rhizome & Antimicrbial, Antiviral \\
\hline 22. & Alovebarbadensis(Liliaceae) $)^{55,56,57}$ & Elva & $\begin{array}{l}\text { Leaves aqueous } \\
\text { extract }\end{array}$ & $\begin{array}{l}\text { Antimicrobial, } \\
\text { Antiseptic, Antiviral }\end{array}$ \\
\hline
\end{tabular}

\section{Possible Preventive measures in Unani medicine for COVID19}

In the light of above observations, the COVID 19 has the manifestation like that of NazlawabaiyaandHummaiWabaiya which are thoroughly mentioned by Unani scholars in their classical texts. Initially it exhibits fever, corrhyza, cough, tingling sensation and or fatigue, headache, sore throat, dyspnoea and digestive troubles etc. sometimes mild and sometimes severe.86 Similar signs and symptoms are also suggested by various Unani scholars like Ibn Sina and other scholars describe under Hummai Wabaiya., 14,17,18 Whereas under the head of NazlaiWabaiya by Samarqandi and other scholar. ${ }^{18,87}$ Jalinoos has mentioned in his book Kitab alHummiyat that it is not possible for any agent to bring about any change in the body unless and until there is any potentiality of acceptance of that particular cause in the body already. ${ }^{2,15}$ It means epidemic affect ones whose constitution is weak. It is clear with the present mode of transmission of COVID-19 that it affects mostly those who have the co-morbidity. In addition, modes of transmission of infection, the detailed description of quarantine concept are also mentioned in Unani and its related literature. ${ }^{8,16}$ In the light of Unani medicine herewith the following measures are suggested to be adopted for the safeguard of epidemics.

Table 2: Drugs prescribed for prevention from Epidemic outbreak. 


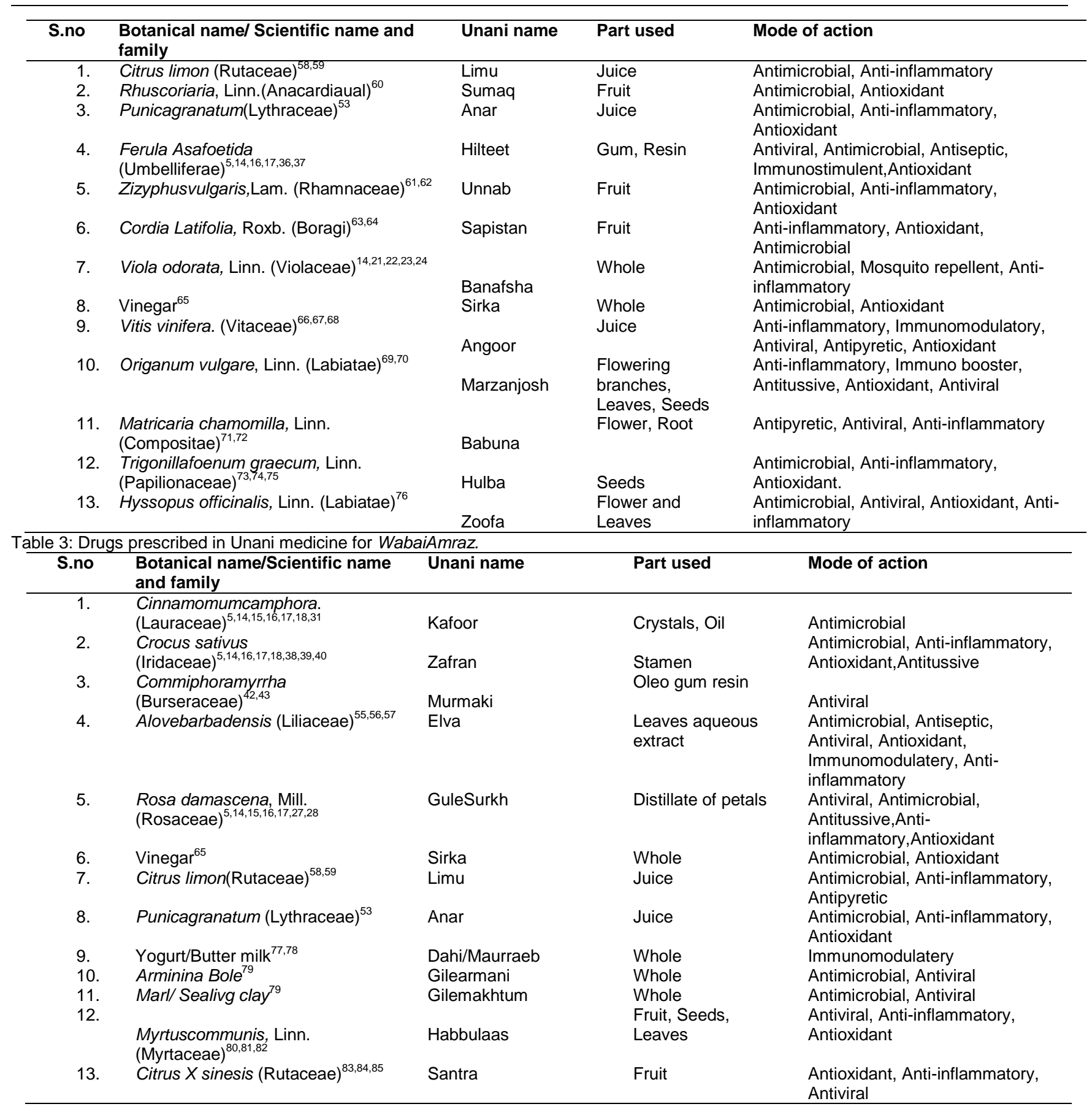

\subsection{Management}

Along with aforementioned general preventive measures the following inputs may also be considered for possible preventive/curative measure of COVID-19.

Produces dryness in the body by any calculus like practicing of bloodletting and elimination of other morbid matter. ${ }^{5,14,15,16,17}$ Qurs Kafoor 2-tab BID orally and cold extracts advised. ${ }^{5,14,16,17}$ Advice decoction of following drugs Behdana $3 \mathrm{gm}$, Unnanb 5 pieces, Sapistan 9pieces along with SharbatBanafsha $25 \mathrm{ml}$ with lukewarm water morning and evening, for the fever Khaksi (Sisymbriumirio, Linn.) $5 \mathrm{gm}$ is added. ${ }^{20,88 \text {, }}$ 
For relieving of headache and body ache given foot-bath by the composition of boiled Gul banafsha $12 \mathrm{gm}$, leaves of Ziziphus jujuba60gms, eight litres water for ten minutes. ${ }^{20}$ In case of cough SharbatBanafsha and SharbatKhashkhash each $12 \mathrm{ml}$ morning and evening. If there is sore throat Sharbat Toot Siyah $24 \mathrm{ml}$ added instead of Sharbat Banasha. ${ }^{20,88}$

For strengthening to the body organs KhamiraGauzaban Ambari Jawaharwala $12 \mathrm{gm}$ or KhamiraGauzaban $12 \mathrm{gm}$ with silver foil paper. ${ }^{20}$ The details of drugs are mentioned in Table 2 and Table 3.

Atibba were well acquainted with such epidemics so they managed very well in those days by employing the concept of distancing, quarantine mode, preventive measures and novel plan of treatment. For instance, administration of Unani formulation like Tiryaqwabai is for two reasons immune modulating agent and antioxidant activity. ${ }^{5,14,15,16,17,18}$ It consists of three ingredients Zafran (Crocus sativus), Sibr/Elwa (Alovebarbandensis), andMurmaki (Commiphora myrrh). The formulation significantly showed the good result on immune compromised elderly patients as it evaluated on elderly patients for their immune stimulating effects. ${ }^{89}$ Elwa has good effect of purgation as quoted by Hippocrates freely given, and a considerable proportion of the cases did wellpurgatives brought about the fortunate results. ${ }^{4,5,14,15,17}$ Already these drugs undergone through animal study and proven antioxidant and immune stimulating effect of $A$. barbdensis, $C$. myrrh and C. sativus. ${ }^{37,38,39,47,48,60,61,89}$ C. Sativus also acts as antitussive due to containing of crocin and safranal. ${ }^{38,39}$

Gulab (Rosa Damascena) has antitussive, bronchodilator, antioxidant and anti-inflammatory effects reported in animal trial. ${ }^{26,27}$ Qust Shirin(S.Lappa) is very much effective due to its antiinflammatory, antiviral, and immunomodulatory activity as claimed by Kulsoomzohra et al. ${ }^{5,14,15,31,32}$ Sumaq (Rhuscoriaria L.) reported as antimicrobial, antioxidant, anti-inflammatory/chondroprotective by the review work of Arham Shabbir 2012. 5,14,15,16,17,60 GilArmani (Arminia Bole) is white layer and Gil Makhtoom (Marl, Sealing clay) is pink layer reported as effective in epidemics. ${ }^{15,16,17,19}$ Since, Shehab et al worked on mineral clays (Gray clay, Yellow clay, White clay,) in vitro study, they found antibacterial effect against staphylococcus aureus that was isolated from the skin infection. On the other hand, pink mineral clay explained as antibacterial effect against Pseudomonas aeruginosa, and has low effect against Staphylococcus aureus. ${ }^{79}$ Sandal surkh (Pterocarpus santalinus) reported as antioxidant, antimicrobial and anti-inflammatory activity by the review work of Bulle $S$ et al.$^{29}$ Due to the presence of phenolic and polyphenolic compounds, such as flavonoids in edible plants exhibit anti-oxidant activity the free radical-scavenging activity of extracts of the leaves of $P$.santalinus has been evaluated in vitro studies. Pterostilbene, methyl ether of reserveratrol has promising effect against anti-inflammatory and antioxidants. ${ }^{29}$
The above-mentioned immune modulatory drugs are easily available, cost effective, economical, and easy to administer to the patient. The mentioned regimens like starvation, Tajfeef, foot bath, Lakhlakha, Istigragh and Fasd can practiced easily and their credible history is very long.

\section{Conclusion}

The ancient physician commonly used the term Epidemic in the same sense as it is understood now, as applying to any disease which attacks a multitude of persons in a locality at any particular period. Study mentions the basic insights regarding epidemics about their causation and management strategies. It is quite clear not that the impure air of the Hippocrates means the mode of infection and the resistance to the disease as immune defence. The host factors that are strengthened using measures adopted by Unani medicine are insightful. There is a lot of scope to search for better management of the epidemics when the facts mentioned in Unani medicine are taken into consideration. Research is needed particularly for the drugs Unani medicine has suggested as they have mentioned their effect in prevention and treatment of the disease. In the light of above description literature of Unani medicine has got insights to manage the epidemics and the experience may prove beneficial in case of COVID-19 management.

\section{References}

1. Vagelpohl, U. (2014). Galeni In HippocratisEpidemiarumlibrum I commentariorum I-III versio Arabica: Edidit, in linguamAnglicamvertit, commentatusest (Vol. 1). Walter de Gruyter GmbH \& Co KG.

2. Majoosi AIA. (2010). Kamilus Sanaa (Urdu translation by Ghulam Hasnain Kantoori). New Delhi.IdaraKitabulShifa.

3. Kabiruddin HM (1930). Kulliyate Qanoon. Vol.1. New Delhi.Daftarul Maseeh.

4. Adams, F. (Ed.). (1886). The genuine works of Hippocrates (Vol. 1). W. Wood.

5. Ibn-Sina. (YNM).SR. Al-Qanoon Fit Tib (Urdu Translation by Ghulam HusnainKantoori). New Delhi.IdaraKitabulShifa.

6. Hajar I. (YNM). BazlulMa'uoon Fi FazlitTau'oon. Riyadh.Darul Asma.

7. StanlyJohny. (2020 April 16). How Pandemics have changed the world. The Hindu Newspaper (Bengaluru City Edition): p12.

8. AS Salabi AM. (2005). SeeratoAmirulMominin Umar bin Abi Khattab ShakhsiyatuhuWaAsruhu. Qahira.Moassissalqra.

9. Fazil NB. (2011). At Tawaeen Fi Sadril Islam Wal KhilafatilUmwiyyah. Majallah Jamia Karkook. Liddarasatullnsaniyyah.

10. IbnKAFH. (1988). Al-BidayaWan Nihaya. 1st edition. Vol. 12 \& 13. Darullhya wat Turas.

11. Ibn, KAFH. (1988). Al-Bidaya WanNihaya. Berut. Maktaba Al Ma'arif.

12. AtTrawana MM. (2010). Al Aubi'aWaA'asariha Al ljtimai Yah Fi Biladish Sham Fi AsrilMamaleek Ash Sharakisa. Al Majallatulurduniyah lit Tareekh Wal Aasar.

13. Al Bazzaz MA. (1992). Tareekh Al Aubi'a Wal Maja'atBil Maghrib Fil QarnainisSamin Wat Tasi'Ashar. Jamia 
Mohammad al Khaamis.ManshuraatKulliyatulAdab Wal Uloom Al Insaniyyah Bir Ribaat.

14. Kabiruddin HM. (1959). Hummiyate Qanoon, Ballimaran Delhi: Daftarul Maseeh.

15. Ibn Rushd AW. (1987). KitabulKulliyat. (Urdu Translation by CCRUM). 1st Ed. NewDelhi.CCRUM.

16. Qumri AMH. (2008). GhinaMuna (Urdu Translation). New Delhi. CCRUM.

17. Razi AMIZ. (2008). KitabulHawi. Vol.15. New Delhi. CCRUM.

18. Aazam. (2011). 'HummiyatWabayee' IkseerAazam. New Delhi.IdaraKitabulShifa.

19. Raazi AMIZ. (1991). KitabulMansoori. New Delhi. CCRUM.

20. Khan HA. (1983). Haziq. Motimahal New Delhi.Jaseem Book Depot.

21. Mittal, P., Gupta, V., Goswami, M., Thakur, N., \& Bansal, P. (2015). Phytochemical and pharmacological potential of viola odorata. International Journal of Pharmacognosy (IJP), 4, 693.

22. Rizwan, K., Khan, S. A., Ahmad, I., Rasool, N., Ibrahim, M., Zubair, M., ... \&Manea, R. (2019). A Comprehensive Review on Chemical and Pharmacological Potential of Viola betonicifolia: A Plant with Multiple Benefits. Molecules, 24(17), 3138, DOI: $10.3390 /$ molecules24173138

23. Zaigham, M. (2019). Phyto-chemical profile and pharmacological activities of Banafsha (Viola odorata Linn): An important herb of Unani Medicine. JOURNAL OF RESEARCH IN TRADITIONAL MEDICINE, 5(3), 58-64.

24. Qasemzadeh, M. J., Sharifi, H., Hamedanian, M., Gharehbeglou, M., Heydari, M., Sardari, M., ... \&Minae, M. B. (2015). The effect of Viola odorata flower syrup on the cough of children with asthma: a double-blind, randomized controlled trial. Journal of evidence-based complementary \& alternative medicine, 20(4), 287-291.

25. Pareek A, Ashwani K. (2016). Pharmocognostic Studies on Nymphea Spp. World Journal of Pharmaceutical Research, 5(6), DOI:10.20959/wjpr20166-6285

26. Sulaiman, G. M., Hussien, N. N., Marzoog, T. R., \&Awad, H. A. (2013). Phenolic content, antioxidant, antimicrobial and cytotoxic activities of ethanolic extract of Salix alba. American Journal of Biochemistry and Biotechnology, 9(1), 41-46. DOI:10.3844/ajbbsp.2013.41.46

27. Boskabady, M. H., Shafei, M. N., Saberi, Z., \&Amini, S. (2011). Pharmacological effects of Rosa damascena. Iranian journal of basic medical sciences, 14(4), 295.

28. Mahboubi, M. (2016). Rosa damascena as holy ancient herb with novel applications. Journal of traditional and complementary medicine, 6(1), 10-16.

29. Bulle, S., Reddyvari, H., Nallanchakravarthula, V., \&Vaddi, D. R. (2016). Therapeutic potential of Pterocarpus santalinus L.: An update. Pharmacognosy reviews, 10(19), 43. DOI: 10.4103/0973-7847.176575.

30. Atia Sharif, H. N., Rehman, R., Mushtaq, A., \& Rashid, U. A (2016) Review on bioactive potential of Benzoin resin. International Journal of Chemical and Biochemical Sciences; 10(1): $106-110$.

31. Hamidpour, R., Hamidpour, S., Hamidpour, M., \&Shahlari, M. (2013). Camphor (Cinnamomumcamphora), a traditional remedy with the history of treating several diseases. Int. J. Case Rep. Images, 4(2), 86-89.

32. Kamalpreet, L. K., Singh, A., Kaur, J., \& Kaur, N. (2019). A brief review of remedial uses of Saussurealappa. Journal of Pharmacognosy and Phytochemistry, 8(3), 4423-4430.

33. Zahara, K., Tabassum, S., Sabir, S., Arshad, M., Qureshi, R., Amjad, M. S., \& Chaudhari, S. K. (2014). A review of therapeutic potential of Saussurealappa-An endangered plant from Himalaya. Asian Pacific journal of tropical medicine, 7 , S60-S69.
34. Mahendra, P., \& Bisht, S. (2012). Ferula asafoetida: Traditional uses and pharmacological activity. Pharmacognosy reviews, 6(12), 141-145.

35. Amalraj, A., \& Gopi, S. (2017). Biological activities and medicinal properties of Asafoetida: A review. Journal of traditional and complementary medicine, 7(3), 347-359.

36. Milind, P., \& Deepa, K. (2011). Clove: a champion spice. Int $J$ Res Ayurveda Pharm, 2(1), 47-54.

37. Hussain, S., Rahman, R., Mushtaq, A., \& El Zerey-Belaskri, (2017) A. Clove: A review of a precious species with multiple uses. International Journal of Chemical and Biochemical Sciences, 11(2017): 129-133.

38. Rezaee-Khorasany, A., Razavi, B. M., Taghiabadi, E., Yazdi, A. T., \&Hosseinzadeh, H. (2019). Effect of saffron (stigma of Crocus sativus L.) aqueous extract on ethanol toxicity in rats: $A$ biochemical, histopathological and molecular study. Journal of ethnopharmacology, 237, 286-299. DOI:10.1016/j.jep.2019.03.048

39. Srivastava, R., Ahmed, H., \& Dixit, R. K. (2010). Crocus sativus L.: a comprehensive review. Pharmacognosy reviews, 4(8), 200-208.

40. Poma, A., Fontecchio, G., Carlucci, G., \&Chichiricco, G. (2012). Anti-inflammatory properties of drugs from saffron crocus. Anti-Inflammatory \& Anti-Allergy Agents in Medicinal Chemistry (Formerly Current Medicinal Chemistry-AntiInflammatory and Anti-Allergy Agents), 11(1): 37-51.

41. Siddiqui, M. Z. (2011). Boswellia serrata, a potential antiinflammatory agent: an overview. Indian journal of pharmaceutical sciences, 73(3): 255.

42. Shameem, I. (2018). Phytochemical \& therapeutic potentials of MurrMakki (Commiphoramyrrha): A review. Indian J Appl Res, 8(9): 102-4.

43. El Ashry, E. S. H., Rashed, N., Salama, O. M., \& Saleh, A. (2003). Components, therapeutic value and uses of myrrh. Die Pharmazie-An International Journal of Pharmaceutical Sciences, 58(3): 163-168.

44. Al-Snafi, A. E. (2016). A review on Cyperusrotundus A potential medicinal plant. IOSR Journal Of Pharmacy, 6(7): 32-48.

45. Bajpay, A., Nainwal, R. C., Singh, D., \& Tewari, S. K. (2018). Medicinal value of Cyperusrotundus Linn: An updated review. Medicinal Plants-International Journal of Phytomedicines and Related Industries, 10(3): 165-170.

46. Imam H, Zarnigar, Sofi G, et al. (2014). The Incredible Benefits of Nagarmotha (Cyperusrotundus). International Journal of Nutrition, Pharmacology, Neurological Diseases.4(1): 25-26.

47. Sivapalan, S. R. (2013). Medicinal uses and pharmacological activities of Cyperusrotundus Linn-A Review. International Journal of Scientific and Research Publications, 3(5): 1-8.

48. Al-Snafi, A. E. (2016). The chemical constituents and pharmacological activities of Cymbopagonschoenanthus: A review. Chemistry Research Journal, 1(5): 53-61.

49. Khadri, A., Neffati, M., Smiti, S., Falé, P., Lino, A. R. L., Serralheiro, M. L. M., \& Araújo, M. E. M. (2010). Antioxidant, antiacetylcholinesterase and antimicrobial activities of Cymbopogon schoenanthus L. Spreng (lemon grass) from Tunisia. LWT-Food Science and Technology, 43(2), 331-336.

50. Chaturvedi, S., Drabu, S., \& Sharma, M. (2012). Antiinflammatory and analgesic activity of Tamarix gallica. Int. J. Pharm. Sci, 4, 653-658.

51. KalamUrfi, M., Badruddeen, J. A., Khalid, M., \&Usmani, A. (2016). Tamarix-gallica-for-traditional-uses-phytochemical-andpharmacological-potentials. J Chem Pharm Res, 8, 809-14.

52. Drabu, S., Chaturvedi, S., \& Sharma, M. (2012). Tamarix gallica-An overview. Asian J Pharm Clin Res, 5(3): 17-19.

53. Miguel, M. G., Neves, M. A., \& Antunes, M. D. (2010). Pomegranate (Punicagranatum L.): A medicinal plant with 
myriad biological properties-A short review. Journal of Medicinal Plants Research, 4(25): 2836-2847.

54. Al-Awwadi, N. A. J. (2017). Potential health benefits and scientific review of ginger. Journal of Pharmacognosy and Phytotherapy, 9(7): 111-116.

55. Akev, N., Can, A., Sütlüpınar, N., Çandöken, E., Özsoy, N., Özden, T. Y., ... \&Üzen, E. (2015). Twenty years of research on Aloe vera. İstanbul Üniversitesi Eczacılık Fakültesi Dergisi, 45(2): 191-215.

56. Mahor, G., \& Ali, S. A. (2016). Recent update on the medicinal properties and use of Aloe vera in the treatment of various ailments. BiosciBiotechnol Res Commun, 9(2): 277-292.

57. Itrat M, Zarnigar. (2013). Aloe Vera: A Review of its Clinical Effectiveness. International Research Journal of Pharmacy, 4(8): 75-79.

58. Al-Qudah, T. S., Zahra, U., Rehman, R., Majeed, M. I., Sadique, S., Nisar, S., ... \&Tahtamouni, R. W. Lemon as a source of functional and medicinal ingredient: A review. International journal of Chemical and Biomedical sciences, 14: $55-61$

59. Dev, C., \& Nidhi, S. R. R. S. (2016). Basketful benefit of Citrus limon. International Research Journal of Pharmacy, 7(6), 1-3.

60. Shabbir, A. (2012). Rhuscoriarialinn, a plant of medicinal, nutritional and industrial importance: a review. J Anim Plant Sci, 22(2), 505-512.

61. Hasan, N. M., Al Sorkhy, M. A., \& Al Battah, F. F. (2014). Ziziphus jujube (ennab) of the middle east, food and medicine. Unique J Ayurvedic Herb Med, 2(6): 7-14.

62. Ghobadi, A., AminiBehbahani, F., Yousefi, A., Taghavi Shirazi, M., \&Behnoud, N. (2019). Medicinal and nutritional properties of Ziziphusjujuba Mill. in traditional persian medicine and modern phytotherapy. Crescent J Med Biol Sci, 6(2): 146-50.

63. Jamkhande, P. G., Barde, S. R., Patwekar, S. L., \&Tidke, P. S. (2013). Plant profile, phytochemistry and pharmacology of Cordia dichotoma (Indian cherry): A review. Asian Pacific journal of tropical biomedicine, 3(12): 1009-1012.

64. Prajapati, S. K., Kar, M., Maurya, S. D., Pandey, R., \&Dhakar, R. C. (2017). Exploring phytochemicals and pharmacological uses of Cordia dichotoma (Indian cherry): A review. Journal of Drug Delivery and Therapeutics, 7(6): 125-131.

65. Ali, Z., Wang, Z., Amir, R. M., Younas, S., Wali, A., Adowa, N., \&Ayim, I. (2017). Potential uses of vinegar as a medicine and related in vivo Mechanisms. International Journal for Vitamin and Nutrition Research, 86(3-4): 127-151.

66. Yadav, M., Jain, S., Bhardwaj, A., Nagpal, R., Puniya, M., Tomar, R., ... \& Yadav, H. (2009). Biological and medicinal properties of grapes and their bioactive constituents: an update. Journal of medicinal food, 12(3), 473-484.

67. Imran, M., Rauf, A., Imran, A., Nadeem, M., Ahmad, Z., Atif, M., ... \& Waqar, A. B. (2017). Health benefits of grapes polyphenols. J. Environ. Agric. Sci, 10, 40-51.

68. Xia, E. Q., Deng, G. F., Guo, Y. J., \& Li, H. B. (2010). Biological activities of polyphenols from grapes. International journal of molecular sciences, 11(2): 622-646.

69. Bahmani, M., Khaksarian, M., Rafieian-Kopaei, M., \& Abbasi, N. (2018). Overview of the therapeutic effects of Origanum vulgare and Hypericum perforatum based on Iran's ethnopharmacological documents. Journal of Clinical and Diagnostic Research, 12(7).

70. . Garcia-Beltran, J. M., \& Esteban, M. A. (2016). Properties and application of plants of Origanum sp. genus. SM Journal of Biology, (2), 1.

71. Zadeh, J. B., Kor, N. M., \&Kor, Z. M. (2014). Chamomile (Matricariarecutita) As a Valuable Medicinal Plant. International journal of Advanced Biological and Biomedical Research, 2(3): 823-829.
72. Srivastava, J. K., Shankar, E., \& Gupta, S. (2010). Chamomile: a herbal medicine of the past with a bright future. Molecular medicine reports, 3(6): 895-901.

73. Al-Asadi, J. N. (2014). Therapeutic uses of fenugreek (Trigonellafoenum-graecum L.). Am. J. Soc. Issues Hum.

74. Aher, R. R., Belge, S. A., Kadam, S. R., Kharade, S. S., Misal, A. V., \&Yeole, P. T. (2016). Therapeutic importance of fenugreek (Trigonellafoenum-graecum L.). A review. J Plant Sci Res, 3(1): 149.

75. Kor, N. M., Didarshetaban, M. B., \& Pour, H. S. (2013). Fenugreek (Trigonellafoenum-graecum L.) as a valuable medicinal plant. Int. J. Adv. Biol. Biomed. Res, 1(8): 922-931.

76. Fathiazad, F., \&Hamedeyazdan, S. (2011). A review on Hyssopus officinalis L.: Composition and biological activities. Afr. J. Pharm. Pharmacol, 5(17): 1959-1966.

77. El-Abbadi, N. H., Dao, M. C., \&Meydani, S. N. (2014). Yogurt: role in healthy and active aging. The American journal of clinical nutrition, 99(5), 1263S-1270S.

78. Yadav, A., Jaiswal, P., Jaiswal, M., Kumar, N., Sharma, R., Raghuwanshi, S., ... \&Bisen, P. S. (2015). Concise review: Importance of probiotics yogurt for human health improvement. IOSR Journal of Environmental Science, Toxicology and Food Technology (IOSR-JESTFT), 9(7): 25-30.

79. Lafi, S. A., \& Al-Dulaimy, M. R. (2011). Antibacterial effect of some mineral clays in vitro. Egyptian Academic Journal of Biological Sciences, G. Microbiology, 3(1): 75-81.

80. Alipour, G., Dashti, S., \&Hosseinzadeh, H. (2014). Review of pharmacological effects of Myrtuscommunis $L$. and its active constituents. Phytotherapy research, 28(8): 1125-1136.

81. Miraj, S., \&Kiani, S. (2016). A review study of therapeutic effects of Myrtuscommunis. Der Pharmacia Lettre, 8(9): 281285.

82. Asgarpanah, J., \&Ariamanesh, A. (2015). Phytochemistry and pharmacological properties of Myrtuscommunis $L$.

83. Favela-Hernández, J. M. J., González-Santiago, O., RamírezCabrera, M. A., Esquivel-Ferriño, P. C., \& Camacho-Corona, M. D. R. (2016). Chemistry and Pharmacology of Citrus sinensis. Molecules, 21(2): 247.

84. Etebu, E., \&Nwauzoma, A. B. (2014). A review on sweet orange (Citrus sinensis L Osbeck): health, diseases and management. American Journal of Research Communication, 2(2): 33-70.

85. Milind, P., \& Dev, C. (2012). Orange: range of benefits. Int Res J Pharm, 3(7): 59-63.

86. Cui, H. T., Li, Y. T., Guo, L. Y., Liu, X. G., Wang, L. S., Jia, J. W., ... \& Wang, H. W. (2020). Traditional Chinese medicine for treatment of coronavirus disease 2019: a review. Traditional Medicine Research, 5(2): 65-73.

87. Kirmani NAA. (2009). SharahAsbabWa Alamat (Urdu Translation ByKabiruddin A). New Delhi: IdaraKitabulShifa.

88. Jurjani IA. (2010). ZakhiraKhawārzam Shahi (Urdu translation by Hadi Husain Khan). Vol. 6 \& $10 \mathrm{New}$ Delhi.IdaraKitabushShifa.

89. Nigar, Z., \&ltrat, M. (2013). Evaluation of a Unani polyherbal formulation (Tiryaqewabai) as an immunostimulator in elderly persons. Ancient science of life, 33(2): 119. 